\title{
RANCANG BANGUN APLIKASI INFORMASI UNIVERSITAS BENGKULU SEBAGAI PANDUAN PENGENALAN KAMPUS MENGGUNAKAN METODE MARKERLESS AUGMENTED REALITY BERBASIS ANDROID
}

\author{
Abdur Rahman $^{1}$, Ernawati $^{2}$, Funny Farady Coastera ${ }^{3}$ \\ ${ }^{1,2,3}$ Program Studi Teknik Infomatika, Fakultas Teknik, Universitas Bengkulu. \\ Jl. WR. Supratman Kandang Limun Bengkulu 38371A INDONESIA \\ (telp: 0736-341022; fax: 0736-341022) \\ 1'adegz_aveiro@yahoo.com, ${ }^{2}$ w_ier_na@yahoo.com, ${ }^{3}$ ffaradyc@gmail.com
}

\begin{abstract}
ABSTRAK
Tujuan penelitian ini ialah untuk membangun sebuah aplikasi yang dapat memberikan informasi tentang kampus Universitas Bengkulu pada smartphone android yang dapat digunakan oleh mahasiswa dan masyarakat, sehingga informasi dapat menyebar luas dan diperoleh dengan mudah. Aplikasi ini juga memudahkan pencarian data karyawan dan menemukan lokasi fasilitas kampus dengan memanfaatkan peta dari Google maps dan teknologi Markerless Augmented Reality menunjukkan lokasi fasilitas dalam kampus. Aplikasi ini dibuat menggunakan bahasa pemrograman Java untuk android dengan IDE Eclipse 3.5. Metode yang digunakan dalam pengembangan program ini adalah model yang linier sekuensial dengan Unified Modelling Language (UML) sebagai desain sistem. Hasil penelitian ini adalah sebuah aplikasi informasi kampus Universitas Bengkulu yang dapat digunakan sebagai pedoman pada smartphone android dengan tampilan yang user friendly dan mudah digunakan.
\end{abstract}

Kata Kunci: Android, Bengkulu University, Google Maps, Markerless Augmented Reality,UML, Location-Based Service.

\section{PENDAhUluan}

\section{A. Latar Belakang}

Universitas Bengkulu merupakan salah satu Perguruan Tinggi Negeri yang ada di Kota Bengkulu yang tersebar pada tiga lokasi yaitu Kampus Induk (Kandang Limun), Air Sebakul dan Cimanuk. Kampus Induk Universitas Bengkulu berlokasi di Kelurahan Kandang Limun, Kecamatan Muara Bangkahulu Kota Bengkulu. Dengan luas lahan 97.84 Ha [1].

Informasi mengenai kampus merupakan suatu hal yang penting untuk memberikan pemahaman atau informasi kepada masyarakat luas mengenai Universitas Bengkulu. Bagi mahasiswa, biasanya informasi mengenai kampus didapatkan pada saat kegiatan pengenalan kampus atau yang lebih dikenal dengan program OSPEK (Orientasi Studi dan Pengenalan Kampus). Namun, meskipun telah mengikuti program OSPEK tetapi masih banyak mahasiswa baru yang belum mengetahui secara detail mengenai kampusnya sendiri, baik dari sarana, fasilitas, gedung kampus, informasi terbaru dikampus, ketersediaan komputer bagi mahasiswa yang tersedia di beberapa gedung, daerah sekitar kampus, transportasi yang dapat digunakan mahasiswa menuju kampus dan nama-nama karyawan. Informasi karyawan Universitas Bengkulu, baik informasi pegawai dan informasi dosen cukup sulit didapatkan. Mahasiswa pada umumnya memiliki kendala dalam mencari data dari pegawai yang dicarinya dan masalah utama yang sering di temui adalah mahasiswa kesulitan mencari NIP dan nama lengkap dari dosen mereka sendiri.

Selain informasi karyawan, kendala lainnya adalah mencari lokasi sarana Kampus Universitas Bengkulu. Kampus Universitas Bengkulu tidak hanya digunakan oleh mahasiswa untuk menuntut ilmu tetapi juga untuk masyarakat umum. Sebagai contoh, dijadikannya tempat ujian bagi para calon mahasiswa baru, resepsi pernikahan, pelatihan, seminar, acara perpisahan dan berbagai perlombaan.

Masyarakat yang menggunakan kampus Universitas Bengkulu banyak yang kesulitan dalam mencari lokasi terkait yang dibutuhkan. Ini disebabkan karena tidak semuanya mengetahui pasti jalan dan lokasi sarana yang ada di kampus Universitas Bengkulu terutama untuk orang yang baru pertama kali mendatangi kampus Universitas Bengkulu. Informasi yang tersusun dengan baik dan rapi akan memudahkan masyarakat mencari informasi mengenai kampus Universitas Bengkulu.

Kampus Universitas Bengkulu memiliki berbagai sistem informasi yang sudah diterapkan untuk mendukung proses pendidikan di dalamnya. Penerapan berbagai sistem informasi tersebut ada yang bersifat lokal dan ada juga yang online. Website merupakan media online yang berperan sebagai media informasi, media pendidikan, media 
promosi, dan media pemasaran bagi Kampus Universitas Bengkulu. Namun website kampus Universitas Bengkulu saat ini lebih banyak memuat informasi pemberitaan. Sedangkan informasi utama berkenaan dengan kampus Universitas Bengkulu yang ditampilkan pada "slider main menu" pada website belum memberikan informasi mengenai kampus secara jelas. Peta kampus pun tidak tersedia pada website ini, sehingga pengunjung website (masyarakat) kesulitan untuk mencari informasi gedung dan hal lainnya.

Dengan demikian perlu adanya alternatif media untuk memudahkan akses bagi masyarakat dan mahasiswa mendapatkan informasi. Permasalahan diatas dapat diselesaikan dengan adanya sebuah aplikasi dimana aplikasi tersebut memuat data sebagai berikut:

1. Kampus saku: berisi data Universitas Bengkulu, struktur organisasi, unsur penunjang, dan unsur kelengkapan.

2. Peta: Peta Kampus Universitas Bengkulu berbasis augmented reality.

3. Cari Karyawan: Pencarian identitas karyawan.

Basis data yang berguna untuk membangun suatu aplikasi yang memberikan informasi digunakan untuk mencegah adanya pengulangan data yang sama dan memberikan kemudahan dalam mengakses data. Dengan adanya basis data ini akan membantu pendataan sarana dan prasarana di kampus Universitas Bengkulu sehingga keberadaan informasi integrasi kampus Universitas Bengkulu mudah diperoleh dan diakses melalui teknologi yang ada.

Pada saat ini mulai berkembang ditengah masyarakat smartphone dengan sistem operasi Android yang merupakan sistem operasi berbasis Linux. Android menyediakan platform terbuka bagi para pengembang untuk menciptakan aplikasi sendiri. Jenis aplikasi yang sudah dikembangkan antara lain aplikasi peta, kamus, dan lain-lain. Untuk itu penulis akan mencoba membuat aplikasi yang memuat informasi yang tersusun secara rapi sesuai sub-informasinya yang dibutuhkan oleh mahasiswa dan masyarakat yang ingin mengetahui kampus Universitas Bengkulu. Dengan adanya aplikasi ini diharapkan mampu menggambarkan kondisi umum kampus Universitas Bengkulu secara lebih detail tanpa harus membuka media lainnya. Aplikasi ini juga memberikan kemudahan dalam mencari lokasi sarana kampus dengan menggunakan augmented reality pada smartphone android.

\section{B. Rumusan Masalah}

Berdasarkan latar belakang di atas, maka rumusan masalah dalam penelitian ini adalah:
1. Bagaimana merancang dan membangun aplikasi informasi Universitas Bengkulu sebagai panduan lengkap pengenalan kampus berbasis android?

2. Bagaimana membuat suatu sistem yang dapat membantu pengguna dan pihak yang berkepentingan dalam memperoleh informasi kampus Universitas Bengkulu?

\section{Tujuan Penelitian}

Tujuan yang ingin dicapai dari penelitian ini adalah merancang dan membangun aplikasi informasi Universitas Bengkulu sebagai panduan pengenalan kampus berbasis android.

\section{Manfaat Penelitian}

Adapun Manfaat dari penelitian ini adalah sebagai berikut:

1. Membantu masyarakat dan mahasiswa dalam mencari informasi kampus Universitas Bengkulu melalui smartphone berbasis android.

2. Bagi instansi Universitas Bengkulu, aplikasi ini dapat menjadi media alternatif dalam penyebaran informasi kampus Universitas Bengkulu.

\section{LANDASAN TEORI}

\section{A. Sistem Informasi}

Sistem informasi adalah suatu sistem dalam suatu organisasi yang mempertemukan kebutuhan pengolahan transaksi harian yang mendukung fungsi operasi organisasi yang bersifat manajerial dengan kegiatan strategi dari suatu organisasi untuk dapat menyediakan kepada pihak luar tertentu dengan informasi yang diperlukan untuk pengambilan keputusan [2].

\section{B. Augmented Reality}

Augmented Reality didefinisikan sebagai penggabungan benda-benda nyata dan maya di lingkungan nyata. Hasilnya ditampilkan secara interaktif dan dalam waktu nyata (real time).Sistem informasi adalah suatu sistem dalam suatu organisasi yang mempertemukan kebutuhan pengolahan transaksi harian yang mendukung fungsi operasi organisasi yang bersifat manajerial dengan kegiatan strategi dari suatu organisasi untuk dapat menyediakan kepada pihak luar tertentu dengan informasi yang diperlukan untuk pengambilan keputusan [3].

Ada beberapa metode yang digunakan pada Augmented Reality yaitu marker based tracking dan markerless.

1. Marker based tracking: Marker based tracking adalah AR yang menggunakan 
marker atau penanda objek dua dimensi yang memiliki suatu pola yang akan dibaca komputer melalui media webcam atau kamera yang tersambung dengan komputer, biasanya merupakan ilustrasi hitam dan putih persegi dengan batas hitam tebal dan latar belakang putih.

2. Markerless: Dengan metode markerless pengguna tidak perlu lagi mencetak sebuah marker untuk menampilkan elemen-elemen digital. Dalam hal ini, marker yang dikenali berbentuk posisi perangkat, arah, maupun lokasi.

\section{Markerless Augmented Reality}

Salah satu metode augmented reality yang saat ini sedang berkembang adalah metode Markerles augmented reality, dengan metode ini pengguna tidak perlu lagi mencetak sebuah marker untuk menampilkan elemen-elemen digital. Dalam hal ini, marker yang dikenali berbentuk posisi perangkat, arah, maupun lokasi. Total Immersion dan Qualcomm adalah salah satu perusahaan yang mengembangkan Augmented Reality dengan berbagai macam teknik Markerless Tracking diantaranya Face Tracking, 3D Objects Tracking, Motion Tracking dan GPS Based Tracking [4].

1. Face Tracking: Dengan menggunakan algoritma yang mereka kembangkan, komputer dapat mengenali wajah manusia secara umum dengan cara mengenali posisi mata, hidung, dan mulut manusia, kemudian akan mengabaikan objekobjek lain di sekitarnya seperti pohon, rumah, dan benda-benda lainnya. Teknik ini pernah digunakan di Indonesia pada Pekan Raya Jakarta 2010 dan Toy Story 3 Event.

2. 3D Object Tracking: Berbeda dengan Face Tracking yang hanya mengenali wajah manusia secara umum, teknik 3D Object Tracking dapat mengenali semua bentuk benda yang ada disekitar, seperti mobil, meja, televisi, dan lain-lain.

3. Motion Tracking: Pada teknik ini komputer dapat menangkap gerakan, Motion Tracking telah mulai digunakan secara ekstensif untuk memproduksi film-film yang mencoba mensimulasikan gerakan. Contohnya pada film Avatar, di mana James Cameron menggunakan teknik ini untuk membuat film tersebut dan menggunakannya secara real time.

4. GPS Based Tracking: Pengembangan teknik ini lebih diarahkan pada smartphone, karena teknologi GPS dan kompas yang tertanam pada smartphone tersebut. Dengan memanfaatkan fitur GPS yang berfungsi sebagai penentu lokasi pengguna pada saat itu berada sehingga lokasi terdekat yang ingin dituju dapat dilihat melalui implementasi augmented reality.

Teknik ini berguna sebagai pemandu selayaknya fungsi GPS, namun dilengkapi dengan marker informasi arah yang dituju. Dalam implementasinya, teknik ini mengharuskan tersambungnya koneksi GPS dan kebutuhan paket data yang ada pada smartphone, karena data-data lokasi yang dimiliki GPS memiliki akses langsung dari satelit agar cepat mendeteksi wilayah yang telah dijadikan sebuah objek marker informasi pada Augmented Reality. Akses internet memiliki fungsi sebagai pemanggilan data-data berupa latitude, longitude, serta informasi yang mendukung setiap lokasi yang disimpan pada server sehingga beban ukuran aplikasi dapat diminimalisir.

Teknik GPS based tracking sebenarnya membutuhkan peran kompas dan akselerometer sebagai pengatur ukuran layar secara horizontal dan vertikal agar marker lokasi dapat dilihat ketika kamera handset berada posisi yang sesuai dengan lokasi tersebut. Namun ketika handset tidak berada dalam sudut pandang lokasi tersebut maka marker tersebut tidak akan tampak.

\section{Android}

Android adalah sebuah sistem operasi untuk perangkat mobile yang berbasis Linux yang mencakup sistem operasi, middleware dan aplikasi.Android menyediakan platform terbuka bagi para pengembang buat menciptakan aplikasi mereka.Awalnya, Google Inc. membeli Android Inc. yang merupakan pendatang baru yang membuat peranti lunak untuk smartphone. Kemudian untuk mengembangkan Android, dibentuklah Open Handset Alliance, konsorsium dari 34 perusahaan peranti keras, peranti lunak, dan telekomunikasi, termasuk Google, HTC, Intel, Motorola, Qualcomm, T-Mobile, dan Nvidia.

Pada saat peluncuran perdana Android, 5 November 2007, Android bersama Open Handset Alliance menyatakan mendukung pengembangan standar terbuka pada perangkat seluler. Di lain pihak, Google merilis kode-kode Android di bawah lisensi Apache, sebuah lisensi perangkat lunak dan standar terbuka perangkat seluler.

Di dunia ini terdapat dua jenis distributor sistem operasi Android.Pertama yang mendapat dukungan penuh dari Google atau Google Mail Services (GMS) dan kedua adalah yang benar-benar bebas distribusinya tanpa dukungan langsung Google atau dikenal sebagai Open Handset Distribution (OHD).

Android merupakan generasi baru platform mobile dan merupakan platform yang memberikan pengembang untuk melakukan sesuai dengan yang diharapkannya. Pengembang aplikasi Android 
diperbolehkan untuk mendistribusikan aplikasi mereka dibawah skema lisensi apapun yang mereka inginkan. Pengembang memiliki beberapa pilihan ketika membuat aplikasi berbasis Android. Aplikasi Android dapat dikembangkan pada sistem operasi berikut [5]:

1. Windows XP/Vista/Seven

2. Mac OS (Mac OS X 10.4.8 atau yang lebih baru)

3. Linux

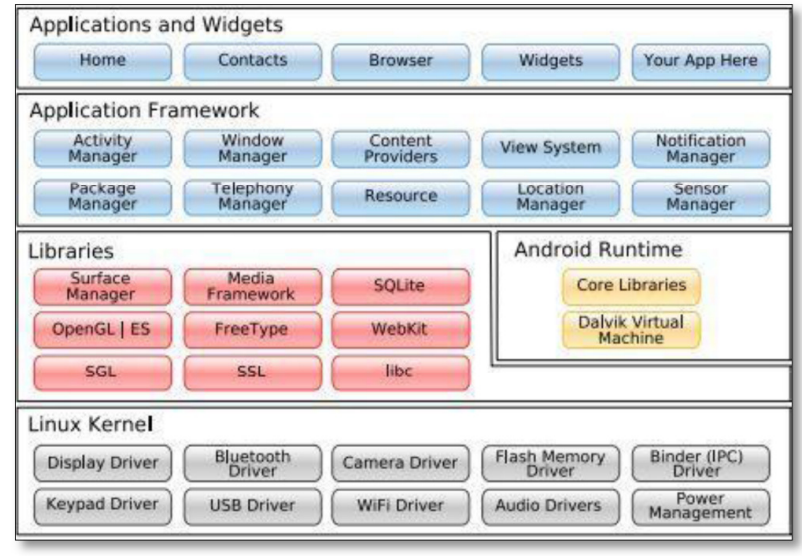

Gambar 1. Arsitektur Android [6]

\section{Metode Penelitian}

Langkah-langkah yang dilakukan dalam penelitian ini adalah:

1. Studi Pustaka: Studi kepustakaan yang digunakan yaitu buku-buku dan jurnal yang berkaitan dengan informasi kampus Universitas Bengkulu, Augmented Reality based location dan bahasa pemrograman Java for Android.

2. Wawancara: Wawancara dilakukan terhadap individu yang mengetahui tentang data dan informasi masalah yang dibahas dalam penelitian ini yaitu Bapak Dr.Ir.Fahrurrozi, M.Sc dan Ibu Dra. Proklampiati, M.M. Adapun sebagai lokasi wawancara adalah Rektorat Universitas Bengkulu Bagian Pendidikan dan Evaluasi.

3. Angket: Angket disebarkan secara acak kepada masyarakat dan mahasiswa Universitas Bengkulu sebanyak 100 angket.

Kampus Universitas Bengkulu memiliki beberapa media dalam pengenalan lingkungan kampusnya yaitu media website dan buku panduan akademik. Akan tetapi ke dua media tersebut masih kurang begitu memberikan informasi secara lengkap mengenai kampus Universitas Bengkulu. Pada website kampus Universitas Bengkulu, informasi yang ditampilkan sangat kurang, masih terdapat banyak menu utama yang tidak memiliki info dan link tidak berjalan, terlebih lagi peta kampus pun tidak ada.

Untuk buku panduan akademik pun hanya dimiliki oleh mahasiswa dan hanya memberikan informasi akademis saja. Salah satu solusi bagi masyarakat dan mahasiswa sendiri dalam mendapatkan informasi dan lokasi sarana dengan metode wawancara berupa tanya jawab. Tanya jawab tersebut dilakukan antar sesama masyarakat, mahasiswa ataupun pegawai di kampus Universitas Bengkulu. Oleh karena itu, diperlukan suatu aplikasi yang dapat memberikan informasi lengkap mengenai kampus Universitas Bengkulu dan lokasi sarana kampus Universitas Bengkulu yang lengkap dan mudah dalam penggunaannya.

Analisis sistem adalah penelitian atas sistem yang telah ada dengan tujuan untuk merancang sistem yang baru atau diperbarui. Tahap analisis sistem ini merupakan tahap yang sangat kritis dan sangat penting, karena kesalahan di dalam tahap ini akan menyebabkan juga kesalahan di tahap selanjutnya.

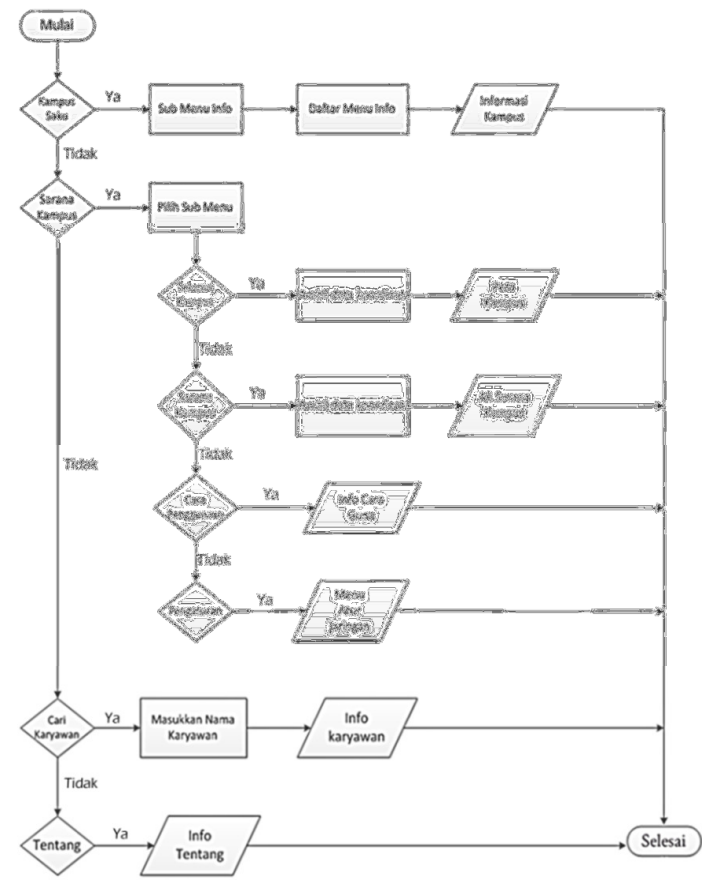

Gambar 2. Alur Aplikasi Kampus Universitas Bengkulu

Perancangan aplikasi kampus Universitas Bengkulu ini menggunakan 7 macam model diagram UML, yaitu use case diagram, activity diagram, sequence diagram, class diagram, object diagram, state chart diagram dan collaboration diagram.

Usecase diagram digunakan untuk menggambarkan interaksi antara pengguna sistem 
(actor) dengan sistem atau kasus, dan disesuaikan dengan langkah-langkah yang telah ditentukan. Aktor menggambarkan orang, sistem atau external entita/stakeholder yang menyediakan atau menerima informasi dari sistem. Berikut use case diagram dari sistem yang dibangun:

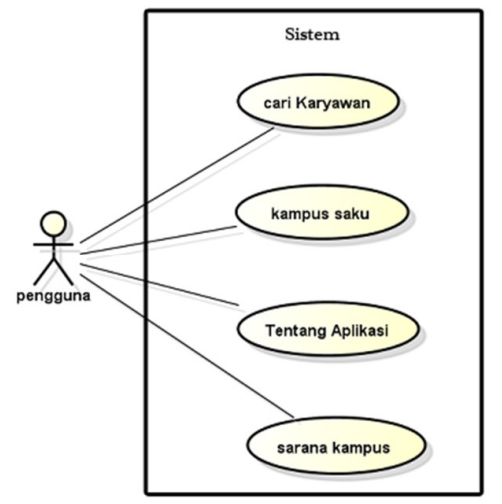

Gambar 3. Use Case Diagram

\section{HASIL DAN PEMBAHASAN}

\section{A. Pembuatan Markerless Augmented Reality}

Dalam pembuatan metode markerless augmented reality berbasis lokasi yang digunakan untuk menampilkan titik lokasi dari menu sarana kampus Universitas Bengkulu, dilakukan beberapa langkah yaitu:

1. Melakukan tracking setiap lokasi sarana kampus Universitas Bengkulu dengan menggunakan GPS untuk mendapatkan titik koordinat dari masing-masing sarana kampus. Daftar nama dan koordinat sarana kampus dapat dilihat pada lampiran $\mathrm{C}$.

2. Membuat gambar untuk masing-masing point of interest (POI) yang akan digunakan sebagai penanda dari sarana kampus yang ada di kampus Universitas Bengkulu.

3. Melakukan pengimplementasian metode markerless augmented reality dengan menggunakan bantuan IDE Eclipse 3.5 Galileo dan framework augmented reality BeyondAR.

4. Dalam pengoperasian aplikasi informasi kampus Universitas Bengkulu yang dibuat dengan metode markerless augmented reality ini, diperlukan minimal spesifikasi yaitu sebuah perangkat smartphone Android dengan sistem operasi Gingerbread 2.3 (SDK 8) yang memiliki GPS dan Google play service.

\section{B. Hasil Implementasi Aplikasi Pada Smartphone Android}

Aplikasi panduan kampus Universitas Bengkulu diujicobakan pada OS Android Gingerbread 2.3. Berikut ini akan ditampilkan hasil pengujian aplikasi panduan kampus Universitas Bengkulu pada smartphone android:

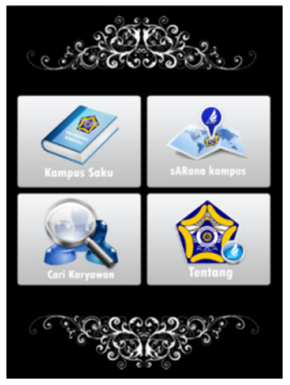

Gambar 4 .Menu Utama

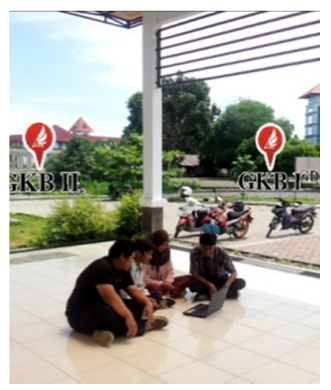

Gambar 6. Markerless Augmented Reality Sarana Kampus

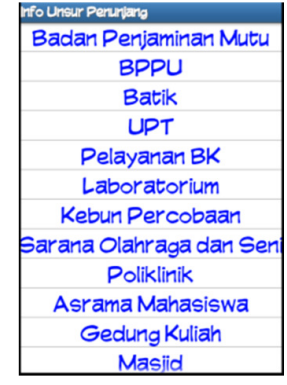

Gambar 5. Informasi Kampus Saku

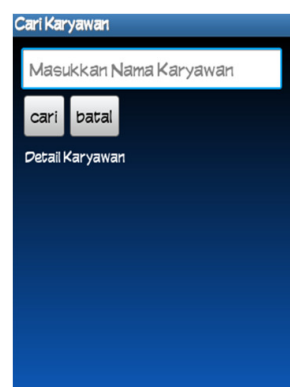

Gambar 7. Pencarian

Karyawan

\section{Pengujian Ketepatan Titik Lokasi Peta dan Markerless AR}

Pengujian ketepatan titik lokasi pada peta dan kamera berbasis augmented reality dilakukan untuk menunjukkan keakuratan sistem dengan keadaan yang sebenarnya saat pengguna menggunakan sistem. Pengujian diambil pada kasus pengguna mencari lokasi Gedung $\mathrm{C}$ dari posisi berada di dekat Rektorat kampus Universitas Bengkulu. 


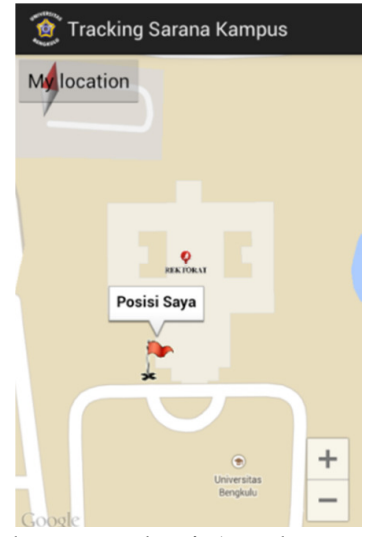

Gambar 7. Lokasi Awal Pengguna

Saat pengguna menggunakan menu Sarana Kampus, pengguna terlebih dahulu masuk ke sub menu Telusuri Kampus untuk mendapatkan titik lokasi posisi pengguna dengan menekan tombol ( Mybcation). Pada gambar 7 dibawah ini terlihat pengguna berada di dekat Rektorat kampus Universitas Bengkulu.

Setelah mendapatkan titik lokasi pengguna dapat melakukan tracking menuju lokasi yang diinginkan, dalam kasus ini pengguna menuju ke Gedung C. Posisi pengguna akan berubah mengikuti lokasi berdiri pengguna seperti terlihat pada gambar 8 dibawah ini.

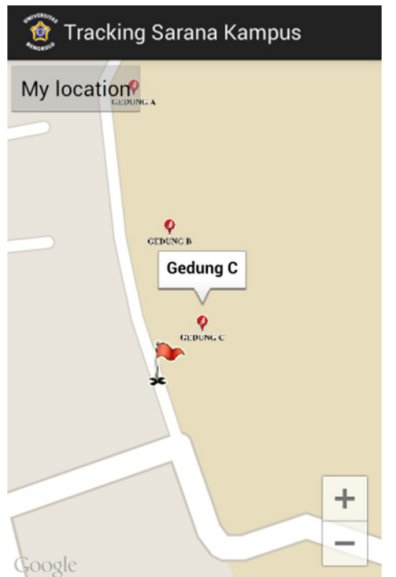

Gambar 8. Lokasi Akhir pengguna

Saat pengguna sampai di dekat lokasi Gedung C, pengguna dapat memastikan dengan pasti titik lokasi apakah benar atau tidak dengan menggunakan sub menu Sarana Kampus yang akan langsung membuka kamera pada smartphone pengguna dan menunjukkan titik lokasi Gedung yang dicari seperti pada gambar 9 dibawah ini.

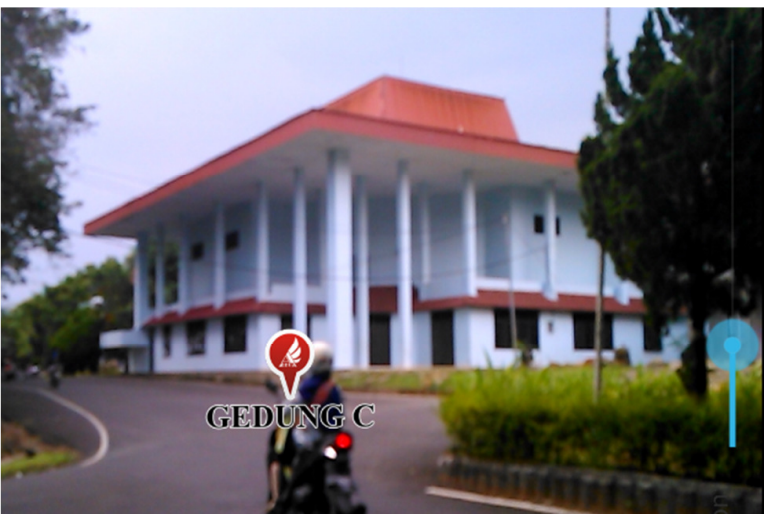

Gambar 9 Titik Lokasi pada kamera

\section{Hasil Uji Kelayakan Sistem}

Pengujian kelayakan sistem bertujuan mendapatkan penilaian langsung terhadap sistem yang dihasilkan. Target dari pengujian kelayakan sistem ini adalah responden (calon pemakai sistem). Tahapan dari uji kelayakan ini adalah dengan menyebarkan angket dan melakukan perhitungan tabulasi data. Dari 100 sampel yang diujicobakan dengan aplikasi Panduan Kampus Universitas Bengkulu, didapat hasil bahwa aplikasi Panduan Kampus Universitas Bengkulu memiliki tampilan yang userfriendly dengan nilai rata-rata 4,38 (sangat baik), mudah dalam penggunaan sistem dengan nilai rata-rata 4,45 (sangat baik) dan memiliki kinerja sistem yang baik dengan nilai rata-rata 4,23 (baik).

\section{KESIMPULAN DAN SARAN}

Dari analisis perancangan serta hasil implementasi program aplikasi yang dilakukan, dapat ditarik kesimpulan yaitu:

1. Aplikasi panduan kampus Universitas Bengkulu memudahkan pengguna dalam mencari informasi kampus Universitas Bengkulu. Dari hasil data angket, aplikasi kampus Universitas Bengkulu memiliki tampilan yang userfriendly dengan nilai kategori sangat baik, mudah dalam penggunaan sistem dengan nilai kategori sangat baik dan memiliki kinerja sistem yang baik dengan nilai kategori baik.

2. Dalam mencari lokasi sarana kampus Universitas Bengkulu pengguna dapat menggunakan peta ataupun kamera dengan menggunakan teknologi augmented reality. Pada pencarian ini tidak dilengkapi dengan arah dan jarak dari lokasi yang akan dicari.

3. Pencarian informasi karyawan terdapat data pegawai yang berisi informasi Nama dan Satuan Kerja. Untuk data dosen hanya untuk dosen yang masih aktif yang berisi informasi NIP, Nama, Jabatan Fungsional, Fakultas, Jurusan dan Prodi. 
Berdasarkan hasil pengerjaan yang diperoleh maka penulis mempunyai saran-saran untuk meningkatkan kinerja aplikasi dan pengembang aplikasi sebagai berikut:

1. Menambahkan layanan web service sehingga informasi yang didapat lebih up to date. Tambahan informasi dapat langsung di update melalui web tanpa harus memperbarui aplikasi android.

2. Aplikasi ini nantinya dapat digunakan pada perangkat bergerak lainnya yang mempunyai sistem operasi tersendiri seperti IPhone dan Blackberry.

\section{PENUTUP}

Tulisan ini dapat selesai tidak lepas dari bantuan berbagai pihak yang telah memberikan kontribusi baik langsung maupun tidak langsung. Terimakasih kepada seluruh mitra bestari untuk menelaah naskah yang dimuat pada edisi ini, dan redaksi Jurnal Teknologi Informasi yang telah memberi kesempatan, sehingga tulisan ini dapat dimuat

"Saya menyatakan dan bertanggung jawab dengan sebenarnya bahwa Artikel ini adalah hasil karya saya sendiri kecuali cuplikan dan ringkasan yang masing-masing telah saya jelaskan sumbernya"

\section{DAFTAR PUStaka}

[1] Fernando, Mario. (2013). Membuat Aplikasi Android Augmented Reality Menggunakan Vuforia SDK dan Unity.Surakarta: AR Online.

[2] Jogiyanto. (2005).Analisis dan Desain Sistem Informasi.Yogyakarta: ANDI.

[3] Nazrudin Safaat, Pemrograman Aplikasi Mobile Smartphone dan Tablet PC Berbasis Android. Bandung: Informatika, 2011

[4] Prihartono, Dhika. (2013). Membuat Aplikasi Game 3D Interaktif Augmented Reality. Surakarta: AR Online.

[5] Unib, Tim. (2013). Buku Panduan Akademik. Bengkulu: Universitas Bengkulu. 